Jared Davidson,

Dead Letters: Censorship and Subversion in New Zealand 1914-1920,

Otago: Otago University Press, 2019, 296 pp

\title{
Censorship and Surveillance in the First World War
}

ROSS WEBB

In his poem, '1 September 1939', W.H. Auden describes a dark and confused world on the brink of the $20^{\text {th }}$ century's second 'total war'. Yet, in the despair, Auden notes that 'dotted everywhere / Ironic points of light / Flash out wherever the Just / Exchange their messages'. In his excellent new book, Dead Letters, archivist and historian Jared Davidson unearths points of light in the darkness that was the First World War. Throughout the book, Davidson introduces us to a range of extraordinary characters whose stories and struggles challenge the nationalist narratives of the war. These historical characters, as introduced in the blurb of the book, include 'a feisty German-born socialist, a Norwegian watersider, an affectionate Irish nationalist, a love-struck miner, an aspiring Maxim Gorky, a cross-dressing doctor, a nameless rural labourer, an avid letter writer with a hatred of war, and two mystical dairy farmers with a poetic bent'. What connects this cast of characters is that their activities, their letters, and in some cases their activism against the war, was of interest to the New Zealand state. The letters they wrote, to loved ones, friends, and comrades, were never delivered, but were intercepted by the state. They are now held at Archives New Zealand, in the Special Registry File, where Davidson discovered them 100 years later. In telling 
their stories, Davidson not only provides a compelling historical narrative, he also contributes to our understanding of the First World War home front, to the early history of surveillance, to the history of political and industrial activism and dissent (often in the most surprising places!), and more broadly to New Zealand social history and the history of the modern state.

The book is divided into three parts. Part one provides the context within which surveillance and censorship took place, and what Davidson calls 'the scheme of surveillance' itself. Postal censorship predated the First World War, Davidson notes, with the New Zealand colonial state opening letters during its first war with Māori. Letters were opened during the Northern War of 1846-1847, and the 1863 invasion of the Waikato was justified by Governor George Grey on details found in intercepted mail. Letters to and from Te Kooti Arikirangi Te Turuki were intercepted and carefully analysed for meaning.' ${ }^{1}$ Surveillance continued over the decades, but it was only after the 1890s, during the creation of the modern New Zealand state, that censorship impacted the lives of Pākehā. By the First World War, postal censorship was, Davidson writes, 'the largest state intrusion into Pakeha private life in New Zealand history'. ${ }^{2}$ Davidson also reminds the reader of the importance of letter writing during this time. In 1914, 110 million letters and 5 million postcards were sent, around 160 items per person in New Zealand. In 1917, 6 million letters were posted each week. The Government censor opened nearly 1.2 million letters during the war.

The first chapter also gives an overview of the social and political backdrop, and Davidson provides an impressive panorama of social history and dissent on the New Zealand home front. It is not the consensus image often presented of the war. Dead Letters reminds us, as Charlotte McDonald writes in the forward, that the First World War was 'fought in conditions of political turbulence'. We are introduced to lesser-known events alongside those that are well remembered. The narrative moves from West Coast miners who downed tools in 1917 to demand an end to military

1 Jared Davidson, Dead Letters: Censorship and Subversion in New Zealand 19141920 (Otago: Otago University Press, 2019), 29.

2 Dead Letters, 24. 
conscription and a rise in wages, the strikes held by woollen mill workers in Petone, resistance to conscription by the Kingitanga, and the arrest of Rua Kenana. In this context, 'police braced themselves for class war'. ${ }^{3}$ In introducing this context, Davidson writes in a beautiful narrative style, capturing the diversity of the personalities of the time and the political turmoil that defined the period. He reminds us, for example, that when Captain Charles Gibbon arrived in Wellington to begin his role as Chief of General Staff (and as Chief Censor) it was only one year after the 1913 strike, of clashes between workers and police on the streets. 'Had he arrived six months earlier', Davidson writes, 'he would have been welcomed with jeers or even a piece of Ghuznee Street ripped up and hurled at him in anger-if his ship had been able to berth at all'. ${ }^{4}$

In parts two and three, Davidson gets into the real guts of the book. Each chapter introduces us to a letter, or a series of letters, and one of the main characters. Each opens with a reproduction of the letter or letters, leaving the reader wanting to know more. These are sources that contain rich details of ordinary life, of resistance, and of lives torn apart by the wartime state. On their own, they are wonderous thing to read; we get a sense of the vernacular, the humour, and the anger of ordinary people.

Here is my favourite. Frank Burns, evading conscription on the West Coast, writes to his ex-sweetheart living in Australia, including a clipping of Fern from the coast, still in the archive 100 years later:

No doubt you will get a surprise when you receive this letter from me, however I know you will forgive me, as position and circumstances which I am under, as you already know, have forbidden me writing previous to this, nevertheless Doll, here I am again having managed to get through a great amount of trouble, which has learnt me a lesson I never will forget. ...

Well Doll, rumours are circulating here to the effect that you have undertook to yourself a husband, cannot believe it myself, but if such is

3 Dead Letters, 45

4 Dead Letters, 21. 
the case remember there is a lad here, waiting to serve you in anyway you like to mention also that all the good luck and happiness that is possible to get, be bestowed on you and the hubby.

Well kid, I had an idea you were going to wait for me, Christ knows where I got the notion from, and I haven't lost it yet. I will wait until your hubby is pushing the daises up, and then arrive and claim you. I will love you all the more when the silver threads are shinning in your dear old barnet-fair.

Anyhow Doll I suppose you would have nothing to do with me now, if you wasn't married, I can't see you having any time for a military evader or shirker old kid. My God it gave me a bump when I heard you were married, but I've got no objections, so go for your life and get all the enjoyment possible to get. ${ }^{5}$

While the letters are interesting in themselves, Davidson is able to bring them to life with his narrative, providing the wider context and the stories behind each letter. The letter quoted above, for example, was never received, and its interception led to Burn's arrest soon after.

A diverse cast of characters are covered. In chapter two we meet Marie Weitzel, 'the only German among the worms, the only one with heart', as she writes. ${ }^{6}$ Davidson describes Weitzel's Buller Street home in Te Aro, Wellington as a place where 'she and her comrades talked, sang, and planned the revolution'. 7 In chapter three, we are introduced to Even Christensen, a Scandinavian waterside worker who describes in a letter that 'the foreman told us that all foreigners working on the wharves and on-board ships must register at the police station'. ${ }^{8}$ Christensen's story provides insight into the larger issues of waterside work, foreign labour, the clampdowns on strikes during the war, and mobility and citizenship when 'the aspiration

5 Frank Burns in Dead Letters, 117-119.

6 Dead Letters, 56.

7 Dead Letters, 69.

8 Dead Letters, 75. 
to control finally coincided with the actual ability to control'. ${ }^{9}$ Once such controls were established, like the surveillance state in general, 'they were not dismantled'. ${ }^{10}$ Chapter seven tells the intriguing story of Hjelmer Von Dannevill, who horrified the officials by challenging gender norms: 'Here was evidence of a masculine, cross-dressing women meddling with a man's wife and shamelessly subverting gender norms. Not only that, she was a suspected enemy alien'. ${ }^{11}$

The greatest strength of the book, and one fairly consistent across the chapters, is the human stories that Davidson reveals. Davidson connects the political protest and dissent of the time to personal lives and, in turn, reveals the ways in which the war and state impositions ruined lives. Christensen was subject to laws impacting foreigners and placed on a 1917 Register of Aliens. 'Behind the stats', Davidson writes, 'lay heartache, the potential loss of civil and legal rights, and - for Evans and his familythe loss of an income when finding work as a "foreigner" was harder than ever'. ${ }^{12}$ Burns describes how the war changed his life:

Well old dear my Christmas festivities were the most troublesome and disappointing ever I experienced so far, not like the previous one kid, when we got together roaming those hills. The one when you was here was all fun and frolic, and this one all sorrow and sadness, so you can imagine what it was like, just the two extremes. What do you think of those policemen, it tells you what they will do, when they watch over a father on his deathbed and also his funeral to try and capture his son for evading and refusing to go and fight their cursed wars. ${ }^{13}$

Hjelmer Von Dannevill not only had her mail censored. She was interned on Matiu/Sommes Island.

After the last five years of centenary celebrations, we might ask why we

9 Dead Letters, 91.

10 Dead Letters, 91.

11 Dead Letters, 166.

12 Dead Letters, 85.

13 Dead Letters, 118. 
need another book about the First World War. But this is exactly the kind of work we need, a work that examines not only New Zealand's role in what Davidson calls 'one of history's most senseless spasms of carnage', but that also provides an insight into the suppression of freedoms on the home front. ${ }^{14}$ The book introduces us to a diverse group of characters, rather than the traditional narratives of dissent and anti-war protest. In doing so, Davidson also avoids repetition across the chapters. Each one delves into a different aspect of New Zealand social history during the war, and a different aspect of dissent. All that connects these characters, in large part, is that they were seen as a threat by the state and had their letters intercepted and placed in the Special Registry File. What is also clear is the depth of research that lies behind this narrative. The writing is not weighed down with quotations and citations, but it is clear that Davidson is drawing on a wide range of sources. For closer readers, the footnotes give a sense of this.

Davidson notes the irony of the story being rooted in the state's archive of censorship: 'To tell such a history is possible only because of censorship and detention of letters through the system of surveillance. We are, at once, critical of and indebted to the state machinery of censorship. ${ }^{15}$ Yet, as Davidson concludes, there is a 'satisfying form of poetic justice' in reproducing these letters and the stories behind them: they are now available to a wider audience. The letter writers are given the chance to tell their own story and be remembered. The question of whether one is remembered or not is, Davidson concludes, 'one of life's final inequities'. ${ }^{16}$ And by giving these stories to the present, Davidson allows these voices and lives from the past to empower the future.

14 Dead Letters, 23.

15 Dead Letters, 16.

16 Dead Letters, 243. 